\title{
Anthrovision
}

Vaneasa Online Journal

$1.1 \mid 2013$

Varia

\section{The funeral fiesta at the Science Museum}

Translating sensory contexts and representing the Mexican Día de los Muertos in an exhibition on food

Susanne B. Schmitt

\section{Q OpenEdition}

\section{Journals}

Electronic version

URL: http://journals.openedition.org/anthrovision/258

DOI: 10.4000/anthrovision.258

ISSN: 2198-6754

\section{Publisher}

VANEASA - Visual Anthropology Network of European Association of Social Anthropologists

\section{Electronic reference}

Susanne B. Schmitt, «The funeral fiesta at the Science Museum », Anthrovision [Online], 1.1 | 2013,

Online since 01 August 2013, connection on 19 April 2019. URL : http://journals.openedition.org/ anthrovision/258; DOI : 10.4000/anthrovision.258

This text was automatically generated on 19 April 2019

(c) Anthrovision 


\section{The funeral fiesta at the Science}

\section{Museum}

Translating sensory contexts and representing the Mexican Día de los Muertos in an exhibition on food

\section{Susanne B. Schmitt}

1 In a small off-space theatre in Berlin-Mitte, the grey concrete floor is shimmering wet. The fiesta is going to start very soon, and I have spent the last hour trying to avoid standing in people's way as they are mopping the floor, setting up the food stall where the pan the muertos and mole will be sold. The candles on the ofrenda, the altar that the Mexican cultural society erected the day before, have not yet been replaced. They have been burning until after midnight yesterday when some of the cultural society's members privately welcomed the angelitos, the small children that they have lost. Today is a day that will be open to the public. As a filming anthropologist, I will be trying later to navigate my way around a crowd of local visitors, of mourning friends and tourists originally looking for a "Tex-Mex" style restaurant. My role in the noisy affair at the now very silent place - except for the humming vacuum - is, as is often the case with ethnographic endeavours, visually oriented or not, an ambiguous one: I am here to be an interface and a translator, gathering audiovisual material that will soon become part of an exhibit on food in a German Science Museum.

2 The celebration of el día de muertos is one of the most important Mexican holidays culminating on November $1^{\text {st }}$ and $2^{\text {nd }}$ when the deceased family members are invited into their original homes, visiting relatives and friends and the carefully decorated altars that their loved ones have erected for them, the ofrendas (Haley and Fukuda 2004). Todos santos is "a mortuary ritual, which aims at satisfying both the alimentary and emotional needs of departed souls" and of those that have been left behind (Brandes 2006:8).

Dancing skeletons, grinning sugar skulls and the tempting Catrina, a seductive and elegant lady skeleton waving her fan at both dead and living visitors of the feast have become highly visible representations of the event. The iconography and material culture of this - as we will see later: politically - reinvented "Mexican" holiday has also become 
part of the visual culture of the rockabilly, heavy metal and emo youth scenes, the Mexican tourism industry - and many national museum scenes. Artefacts, audiovisual representations and even enactments and celebrations of the Mexican días de los muertos are especially visible occurrences in Europe and North America.

One of those museums is the Deutsches Hygiene-Museum in Dresden, Germany. In the autumn of 2009, its exhibit on food and drink underwent curatorial revision and major conceptual and architectural modifications were being outlined and prepared. The explicit aim of this project was to represent food as a holistic phenomenon that is deeply interwoven with social and cultural aspects of being human, an approach that extended already existing approaches in the current more "scientific" exhibit.

As part of my ethnographic research project on sensory representation in science museums, I accompanied the curatorial process, attended planning meetings, and was finally asked to contribute my anthropological knowledge to the newly created exhibit. An audiovisual representation of a celebration of todos santos became, for reasons that will be depicted later, part of the planned project along with the collection of suitable museum objects representing the event.

6 In this contribution, I describe the translation of this highly visible event into an audiovisual museum representation. Special regard was given with respect to the senses during the fieldwork and filming process at the two sites of representation and cultural brokerage I became involved with the Deutsches Hygiene-Museum and a "Mexican" cultural society in Berlin. To pursue this line of analysis, I will interrogate the process of approximation and translation through the ethnographic case study of representing the Mexican "Day of the Dead" at the exhibit on food and drink at the Deutsches HygieneMuseum in Dresden, a part of the permanent gallery that is dedicated to the "human being". By doing so I do stress the role of the senses in efforts of museum representation and knowledge production and analyze how my position as an anthropologist and participant observant as a film-maker got me caught up in the politics of (sensory) representation.

\section{Sites of representation: the Science Museum and the Mexican funeral fiesta}

7 Pre- Hispanic and Spanish Catholic influences pervade the Día de los Muertos, a diverse and regionally differentiated celebration in honour of the dead whose touristily most visible adaptation takes place in Oaxaca. Numerous museums host annual enactments of the Día de los Muertos. Among those are the British Museum in London, the Oakland Museum in California, the Peabody Museum of Archaeology and Ethnography at Harvard University, the Museum für Völkerkunde in Hamburg and the Museum für Sepulkralkultur in Kassel, Germany.

8 The Oakland Museum, for example, not only aims its efforts explicitly at the Bay Area's Mexican community (Brandes 2006: 160), but also explicitly announces the event as a sensory experience and emotional frame for grieving for a diverse US-American audience.

9 In the North American context, the strong presence of todos santos in museums can be ascribed to the important role of migrant Mexican communities as potential museum visitors and potential cultural brokers in outreach programs (Carmichael and Sayer 1992: 
71, Brandes 2006: 160ff.). In this context, museums and art galleries have become important and contested forums for social critique and stages for public rituals, expressing political agendas and claims of ethnic identity (Marchi 2009).

10 In spite of the important political re-appropriation of todos santos through migrant communities who demonstrate how museums can serve as "contact zones" for political agendas (Clifford 1999), representations of the celebration often draw on orientalist phantasies about Mexico (Schmidt-Welle 2011): the topos of the stoic Mexican "looking death straight in the eye and laughing at it"(Brandes 2006: 5) and throwing colourful and noisy fiestas, makes it easy to reduce all of Mexico and all Mexicans to such a metaphor regardless even of regional and individual differences of commitment to the event.

The aesthetic contours of the Deutsches Hygiene-Museum in Dresden where I conducted my doctoral fieldwork for more than a year could at first glance not be more different from the media images of the Day of the Dead with its dancing skeletons, colourful sugar skulls and the noble and flirty dame Catrina. Both institutions, however, represent specific ways of engaging with death ${ }^{1}$ offering modes of emotional coping and knowledge production based on differing sensory priorities and prioritisations.

Skeletons, though not dancing ones, are a cornerstone of visual representation at the Hygiene-Museum as well: it is a museum about the human body, health, and illness. At least that is what it used to be when it was founded in the Weimar Republic. The notion of Hygiene was one of the most important medical and socio-political discourses in Germany during the early 20th century. Hygiene was an ensemble of technologies, knowledge and practices that aimed at creating and sustaining a normative and "healthy" body. The public was considered to be in need of information about the prevention of ill health. As a sub-discipline of biomedicine, which became more and more important at that time, hygiene aimed at increasing public health by educating the individual. The most important medium for this were hygiene exhibitions or fairs which were among the most important mass media at the time.

The Deutsches Hygiene-Museum is the result of two hugely successful international exhibitions on the topic of hygiene in Dresden. The first one in 1911 attracted more than five million and the second one in 1930 more than three million visitors. The two International Exhibitions of Hygiene were sponsored by the industrialist and maker of the Odol mouthwash Karl August Lingner. The modernist museum building designed by Wilhelm Kreis (1873-1955) was part of the Second International Exhibition of Hygiene in 1930 and has been the museum's home ever since, now attracting more than 250.000 visitors every year.

Once conceived as a place of public health education and the subjectification of health and medico-scientific innovation, the museum now, after a substantial remodeling during the aftermath of the German reunification, features a permanent gallery on the "Human Adventure" showing aspects of being human from a body-centered perspective. This perspective includes sexuality, dying and movement, a children's museum focusing on the five senses and various special exhibitions.

Today, according to the publicised self-interpretation, it is a "universal museum of man" that is

"neither a science centre nor a special museum devoted to a strictly defined topic area whose 'interests centre on the biological, social, and cultural dimensions of the human being""

(Press Information, Deutsches Hygiene Museum, www.dhmd.de, 11.06.2009.) 

interior of the human body. The subjectification of knowledge about the body was thus supposed to take place mainly through a strategy of conveying visual experience that created an understanding of the body based on medical and scientific practices of representation, such as colourful diagrams and wax models of diseased body parts. one of the challenges encountered during the design process for the new gallery room on food. The reason for this lay in the newly adopted narrative on food and eating which the exhibit's creators had decided to employ in the remodeled display.

\section{Turning "gastrosophical?" Food, Science and the "total phenomenon"}

Science and history museums differ from art museums in their curatorial practices. In the case of the former and especially with science museums, a story and educational narrative are developed before the objects that support that narrative are chosen or even specifically produced (Schildkrout 2006: 130). The Deutsches Hygiene-Museum, as has been outlined above, can be considered as one of a kind of institution that contains elements of historical and medical museums as well as elements of science centres. The script for the new room on food contains features of the old room that presented food with special reference to a healthy diet and the physiological processes taking place while eating.

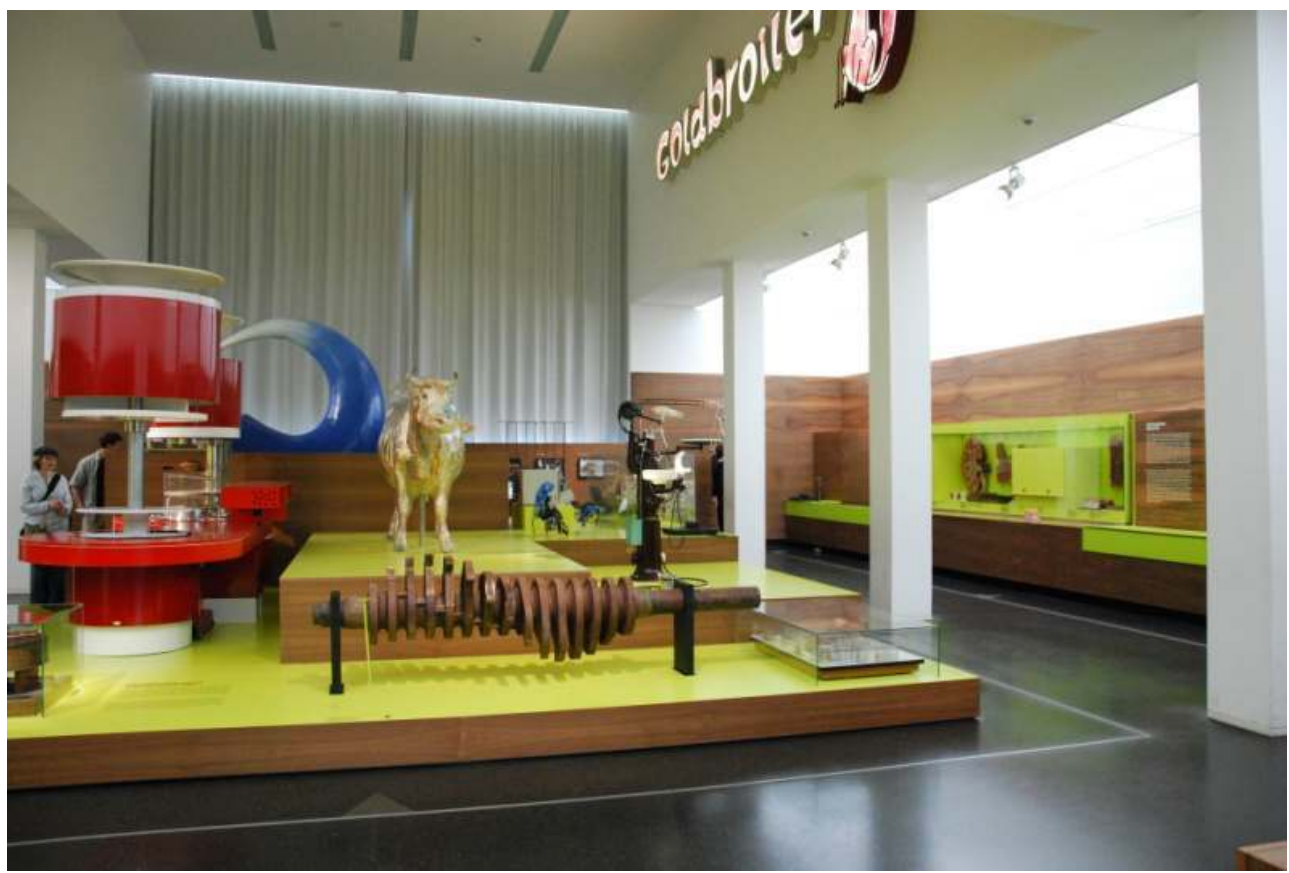

The room “EATING AND DRINKING" in 2009 before its redesign.

PHOTO: SUSANNE SCHMITT

The new script contained, as a strong focus, the social basis and effects of eating on the culinary arts and the pleasurable and indulgent aspects of it. The curator team situated the interconnection of religious and social aspects of eating, as for example in mortuary rituals, the role of global flows for local food practices and the staging and embellishment 
of meals throughout time and space. This was an understanding of food as a holistic and "total" phenomenon that the team attributed to Marcel Mauss. This conception may also be understood in the context of the "gastrosophical turn" (Lemke 2009) of recent years: a critical re-thinking of the meaning of food in the humanities and social sciences and the contemporaneously growing interest of a wider public in cooking shows, slow food and food as a mode to achieving well-being and self-realization (2009: 9). This new conceptualization of food also had an impact on multimedia and multi-sensory representations within the new room. As the curator put it: "[The room on] Food becomes more sensual!"

\section{On museums and the sensory}

20 It is commonly being argued that museums prioritize vision in favour of other forms of sensory access to museum spaces and collections: Classical writings on museums and the senses suggest that the institution be conceived as a panopticonic apparatus exceeding power through visual display and providing a museum experience aiming at a disciplined museum-visitor-citizen. In fact, "the museum" has largely been conceptualized and criticized as a panopticonic apparatus that historically developed out of modes of representing and experiencing knowledge that privileged other ways of sensory access such as touch (Bennett 2008, Losche 2006, Classen and Howes 2006, Classen 2007). Museums, as Susan Stewart reminds us, "[are] so obviously, so, one might say, naturally, empires of sight that it barely occurs to us to imagine them as being organized around any other sense or senses" (Stewart 1999: 28).

This general appraisal is in need of two limitations for the sake of the argument I make here. Firstly, the role of the museum visitor as an already knowledgeable and embodied person has been re-conceptualized in recent years. This is especially true for science centres and science museums. Unlike earlier museum types, science centres aim at producing knowledge through bodily experience. "Science to touch" and "experience science" - those buzzwords inform the discourses surrounding sensory access in science centres that no longer display objects, but favour an experiential and haptic access to knowledge production (Noschka-Roos, Teichmann 2006). Although many of their specifically built interactive displays aim at the visual, they are usually designed to include more senses.

The team who produced the new room on food did not perceive of the museum as a science centre in the strict sense because of its more traditional museum legacy on the one hand and strong (though not exclusive) focus on non-interactive objects on the other. The exhibition, however, was already equipped with a variety of visual-based and auditory interactive installations; interactivity was a strong feature of the new room as well ${ }^{2}$. Secondly, we need to reconsider the situated meanings and practices surrounding the visual.

In my "day to day" fieldwork at the museum, filming had become part of my methodology and daily practice. I had employed it in order to grasp museum employees' and tour guides involvement with the spatial and material dimension of the institution: "goalongs" with my informants had helped me develop a "skilled vision" of the museumscape. I had oftentimes contemplated the images and video footage together with research partners, but never had I had any intentions to produce footage intended for 
public screening. In fact, my fieldwork was strongly influenced by an interpretation of visual anthropology that has been articulated most prominently by Christina Grasseni. Thus, I understood the fieldwork process as a process of "learning to see" like a museum professional. Accordingly, when the curating team came up with the idea to include some audiovisual material on todos santos, I was eager to test out my own newly developed vision.

\section{From Mexico through the supermarket and into the showcase}

Chatting away an afternoon at the museum cafe, the permanent gallery's keeper and I were brainstorming on the "new" room. It was important to the curators that the room conveys a more global perspective on local meanings and practices surrounding food. The first idea that should later become a part of the room were Japanese bento or lunch boxes demonstrating the creative cooking and decorating practices of Japanese mothers when preparing lunches for their children to eat at school. This idea was to be translated into a museum display through images of finished bento boxes that were hung on the wall. Next we came up with the idea of narrating on the intimate relationship of food, memory and social relations through representing the Mexican "Día de los Muertos", as outlined above, quite a visible event in the museum world that we, however, knew little about. This is how our fieldwork began, turning me, the anthropologist, and the curators, into "accomplices" in this stage of my own ethnographic research and their development of an anthropologically informed curating style.

\section{At the supermarket: visualizing a multi-sensory world}

"The exhibit team and I have met in front of a small supermarket in DresdenNeustadt. We came here to learn more about the goods used during the Día de los Muertos. I had noticed the shop window of the small shop a couple of days before. The large white cardboard cross decorated with paper flowers had caught my eye before. It is mid-October and the feast of the dead will take place in two weeks' time. It had been my idea to come here with the team because some of the goods in the shop window could possibly be used at the exhibit after the celebration. The three of us step into the small room that has been painted in warm, earthy colours. The owner rises behind her cashier's desk to greet us while we are browsing the shelves. The head of the curating team introduces ourselves and explains that we come from the Deutsches Hygiene-Museum and plan to include the Day of the Dead in a new exhibit. The owner immediately reaches out for some groceries from the shelves, chocolate amongst them. Over the period of the feast, she explains, it is important to supply the deceased's favorite dishes. Cocoa and chocolate are especially important. She takes a small cocoa box from the storage rack and opens the lid with the invitation: 'Smell it!' As we soon learn, this Guatemalan shop-owner tells us that she had planned to pick out the Day of the Dead as a special topic for her Spanish conversation class tonight. For that purpose she has picked some video footage from the internet that we watch together on her laptop on the big table behind the sales counter. A flood of orange and yellow flowers (tagetes, also called flor de muertos, flower of the dead) and loud music decree my personal experience of watching the footage. Suddenly, yet another person enters the small shop. It is a man of about 40 in dark and elegant clothes. He is working as a Spanish teacher in Dresden as well. As he hears why we are here and that I am an anthropologist he immediately begins to elaborate on the Pre-Hispanic origins of the Day of the Dead. 
He explains about Latin America's colonial background that has shaped the Día de los Muertos as it is today. While the curating team thinks of the Day of the Dead in terms of communication with the deceased, to Luis it touches upon problems of ethnicity and national identity."

(Field notes)

The invitation to smell the cocoa was not what the curating team had come for. Smell was not something that could be displayed. The video footage that the shop-owner had shown us, however, had set itself into the back of their minds. She had downloaded it online, something she could easily and legally do for her private teaching purposes. In the museum context, however, downloading footage from a video portal like YouTube was by no means good practice since the copyright could not be tracked. During the following days, we browsed the net for video footage together and searched ethnographic film databases. The curators' priorities while browsing for audiovisual material were twofold: the ofrendas and the food displayed there needed to be clearly visible - they were to depict the "real" food and would later be supported by other material witnesses like papel picado, pan de muerto and sweets in the showcase. At the same time, the copyright needed to be held by the museum. In the end, the exhibit creators decided to produce some footage of their own and contacted a variety of museums and cultural institutions, following a horizontal scheme of translational authority,. Finally, a Mexican "cultural society" based in Berlin answered and invited us to film their interpretation of a public staging of the day of the dead. Initially, I had planned to accompany the team while they would be shooting the footage with a camera from the museum's technology department.

In the end, I had to go by myself, having been testified the "right way of looking at it" by the team: "You know what we are looking for!" After many months of fieldwork at the museum I was being acknowledged capital that consisted of both a way of seeing and a way of being seen: as a professional who knew what to look for.

According to Mary Bouquet (2001) curating an exhibition and conducting ethnographic fieldwork share a set of common features, amongst them the collection of artifacts and their drawing or photographing of images as conflicts and problems of representation complete the line of similarities. Researching the existing literature on the ofrendas, the icon of the Day of the Dead that the team had picked for visual and material representation, was therefore the first step in the development of the exhibit for the team involved.

\section{The ofrendas}

The gift to the dead is composed of edibles and new fashion items, alcohol, cigarettes and toys for the angelitos, the departed children (Carmichael, Sayer 2005: $17 \mathrm{ff}$.). The rural market life and the offerings of the urban range of goods cater to the needs of the living and the dead weeks and months before the event (ibid.).

The ofrenda where the presents are laid out and arranged, usually consist of a table covered with a tablecloth or an especially embroidered shawl and flowers. A cielo, or "heaven", made from plastic or cloth or the colorful silhouettes papeles recortados or papel picado surround the ofrenda (Carmichael, Sayer 2005: 188). Shaped like a loaf with a cross of bones on top, the pan de muerto, a variety of mole and tortillas are amongst the most characteristic dishes. Depending on the likes and dislikes of the deceased being honored 
at the specific ofrendas, hot chocolate, alcohol and soft drinks complete the offering so the visitors can allay their thirst (Brandes 2006: 77).

Smells, taste and materiality of the fares relate to a whole nexus of interconnected experiences comprised of memory, emotion and multisensory experience. According to Nadia Seremetakis:

"The memory of one sense is stored in another: that of tactility in sound, of hearing in taste, of sight in sound. Storage is always the embodiment and conservation of experiences, persons and matters in vessels of alterity. The awakening of the senses is awakening the capacity for memory, of tangible memory; to be awake is to remember, and one remembers through the senses, via substance"

(Seremetakis 1996: 28).

The preparation of their favorite dishes, their smells and their tastes serve as a connection to friends and family members who have passed. It thus evokes and actualizes the relationship of the living and the dead. The meals thus perform, on symbolic and sensory levels, the function of bridges or channels into the past. The deceased are being commemorated through the prism of their favorite dishes.

The preparation of the dishes and the ofrenda is in fact the prerequisite for their arrival By accommodating the olfactory memories of the dead, their families are helping them to find their way home; the visual senses of the deceased are thought to be very impaired, their sense of smell is, however, even more accurate and they are eagerly awaiting the smells of the dishes and cigarettes that have been provided for them. The smells of specifically used flowers and spices like marigold, tagetes, chili, veruche and cockscomb play an eminent role in the creation of sensory paths that aid the dead in their orientation (Brandes 2006: 20). The visitors are not allowed to enjoy the food other than through its smell which is heightened by the flowers (Haley, Fukuda 2006: 73). This very original smell- and tastescape ${ }^{3}$ is of course not only perceivable for the death but for the living as well: "I smell a fiesta!" (ibid.).

In her book Culinary art and anthropology Joan Adapon illustrates the multifaceted meanings of food based on her ethnography of food and cooking practices in Mipla Alta, a suburb of Mexico City. According to Adapon, food and prepared meals cannot only be understood through their metaphorical and symbolic content but also through their social meaning:

"Food and eating constitute such a domain where social settings exist for people to eat together, making social relations between persons via the meal, and with the food literally ,merging" with these people as they eat it." (Adapon 2008: 47).

As we will later see, during the process of museum translation, sensory aspects beyond the visual became less important. Another aspect that disappeared during the process was their individuality and their inclusion of objects that were not visibly marking alterity, that is, could not be read as "typically Mexican" when out of context, like beer or cigarettes. According to Adapon, the creative and often artistically elaborate ofrendas can be conceptualized as artworks in the sense of Alfred Gell since they embody a variety of different internationalities and agencies while still sharing a set of common characteristics shaped by specific styles of art production (Gell 1998: 153, Adapon 2008: 105). When the ofrendas had to be translated into a visual showcase, the curators tried to "disentangle" this friction between individuality and specific stylistics by excluding allegedly trivial and everyday foodstuffs like alcohol, cigarettes or mole, the chili based sauce also used in other and everyday contexts. Those everyday goods, however, are central to the specific meanings of individual ofrendas and they aptly demonstrate the 
global flow of goods and their local appropriations (Ames 1992: $132 \mathrm{ff}$.). To the curating team, the yet to be filmed footage gained momentum as a representation of all those material elements of the ofrenda that they regarded as less explicit visual signifiers of the fiesta. The "Mexican market"4 that I was to visit as the site of my shooting the footage, however, tried to trigger the imaginary, not by means of visual hints alone but rather through evoking a sensual and tasty experience, a frame of reference rather different from museum expectations.

All those involved in representing the Day of the Dead were therefore part of and actors within a field of cultural brokerage and actively and consciously engaged in efforts of translation between communities and audiences. The Mexican cultural society offered an interpretation of the upcoming festivities that aimed at evoking a specific gustatory sensescape and offered an alternative to the management of emotion allegedly specific to the German context that they considered to be a silent and private way of facing death. The description of the event available online painted the picture of a joyful Mexican market full of new and exotic flavors.

\section{Staging the temporary and sensory materiality of memory and ritual}

In the course of the fiesta, the beginning of the event is clearly marked by visual, auditory and olfactory clues. The light is being dimmed and the music begins to play (see images). Although the memories of the deceased are individual ones, the place that enabled the production of memory was a shared and orchestrated one that had temporarily been carved out of urban space through the creative and strategic use of smells, sounds and lighting. The smoke and smell of the copal (incense) that is burned at both the beginning and the end of the fiesta announce a temporary shift within the urban workaday scape that has been actively produced. This production can be read and experienced as a placemaking activity - an activity that turns space into an appropriated and experienced place - and as part of ritual aesthetics where smells, among other agents, denote phases of ritual (Münster 2001).

In her ethnography of Filipino domestic workers in Hong Kong, Lisa Law describes urban place-making strategies that aim at temporarily evoking Little Manila within the hegemonic space of Hong Kong: "[the] dynamic interaction between food, photos, letters and other artifacts enables the production of an alternative sensorium called Little Manila" (Law 2006: 238). According to Law, the senses are a crucial element of situated practices that empowers and enables the women to experience themselves as national subjects and are a tool for the voicing of ethnicity, memory and belonging. In the middle of Hong Kong's financial district the women openly share meals and memories and adorn their bodies in ways that are deemed inappropriate in their everyday contexts as domestic workers. In a similar manner, through sensory production, the Mexican cultural society also aims at creating a site that evokes an "elsewhere". While Little Manila may be understood as an alternative site of resistance (a political dimension inherent to the Día de los Muertos as well, see above), the sensorial "difference" of todos santos is being instrumentalized in order to attract visitors in Berlin following an invitation to visit a Mexican market serving sweets and regional specialties. The sensory materialization of todos santos can thus be considered from a perspective of religious aesthetics as well as 
from a viewpoint that stresses the politics of representation. Accordingly, aspects of aesthetic expression and cultural production configure one another:

"Aesthetic expression is a phenomenological process of cultural production where a conceptual bricolage is made manifest within a material reality to produce meaning in a structured and dynamic way."

(Sharman 1997: 186, comp. Münster 2001)

The fine line between life and death is crossed in early November and the homecoming of the deceased is enabled through specific sensory practices that, in the Berlin case, do not only attract the dead but also visitors from all walks of life to a site of representation:

"For most of the Mesoamerican peoples, including the Zapotec of central Oaxaca, there is a very fine line that separates the world of the living from the supernatural world where the dead live. On el día de muertos (The Day of the Dead), that line dissolves and, for a time, there is only one world. At that time, November first and second, the dead return to their former homes on earth for a while to eat, to drink, to sing, to be entertained, and to visit with their loved ones."

(Haley, Fukuda 2006: 1.)

Antonio, the leader of the ceremony from the cultural society unveils the ofrenda by blowing on a conch shell trumpet into the four corners of the world while I film him above the backs of the visitors of the crowded theatre. The candles are lit and incense burnt. The stages of segregation and incorporation are being marked through music and smell (Turner 2000). "The dead are now here", a journalist working for the cultural society finally translates for those who are not sufficiently fluent in Spanish. Many of the guests step forward and receive a blessing with the copal (frankincense) from Antonio before they put their photographs and sweets, their CDs with favourite music; Antonio stresses the meaning of the Pre-Hispanic heritage of the event. However, the fiesta remains a polyvalent event, open to appropriation

and interpretation by the guests that have been attracted by the promise of a specific sensescape:

"First, ritual is an event, a set of activities that does not simply express cultural values or enact symbolic scripts but actually effects change in people's perceptions and interpretations. Closely involved with this perspective on ritual events is an appreciation of the physical and sensual aspects of ritual activity. Some theorists appeal to kinesthesia, the sensations experienced by the body in movement, while others appeal to synesthesia, the evocation of a total, unified, and overwhelming sensory experience."

(Bell 1997: 74) 
Using a conch shell trumpet, Antonio calls into the four corners of the earth to invite the Dead

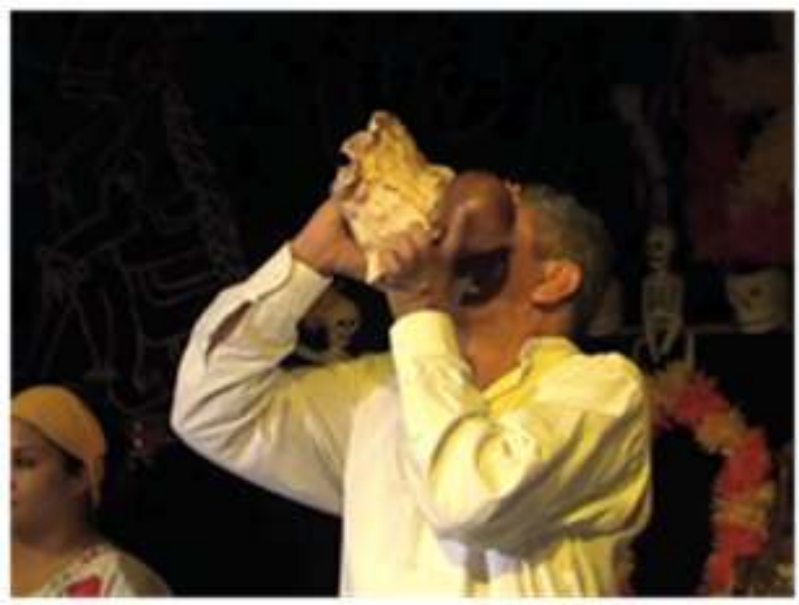

Screenshot: Susanne Schmitt

Details of the ofrenda with family pictures, candles and home-made cake

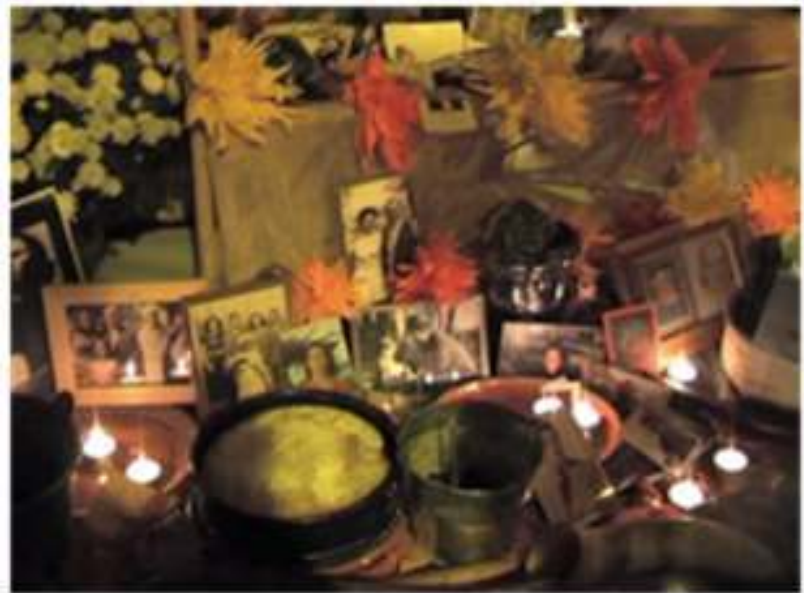

SCREENSHOT: SUSANNE SCHMITT 
Pan de muertos, the bread of the dead, and paper flowers symbolizing the four cardinal points

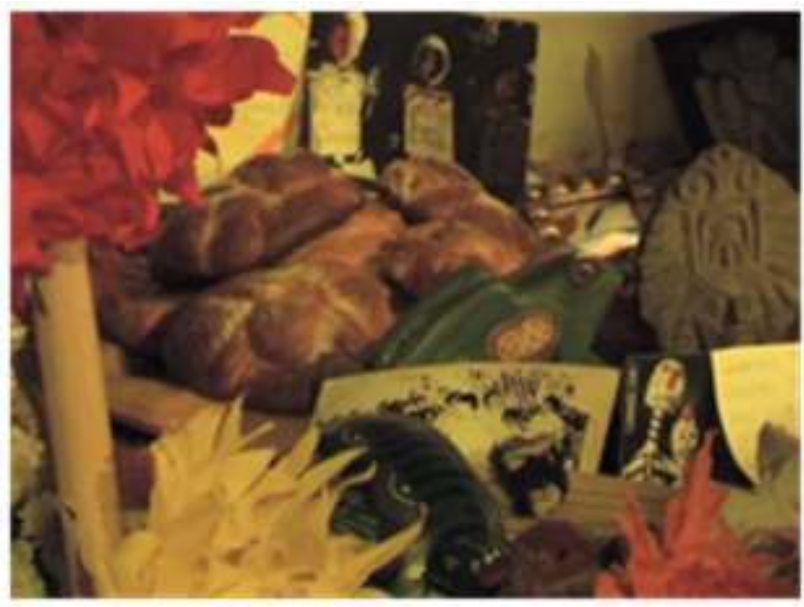

Screenshot: Susanne Schmitt

The disclosure of the ofrenda with incense

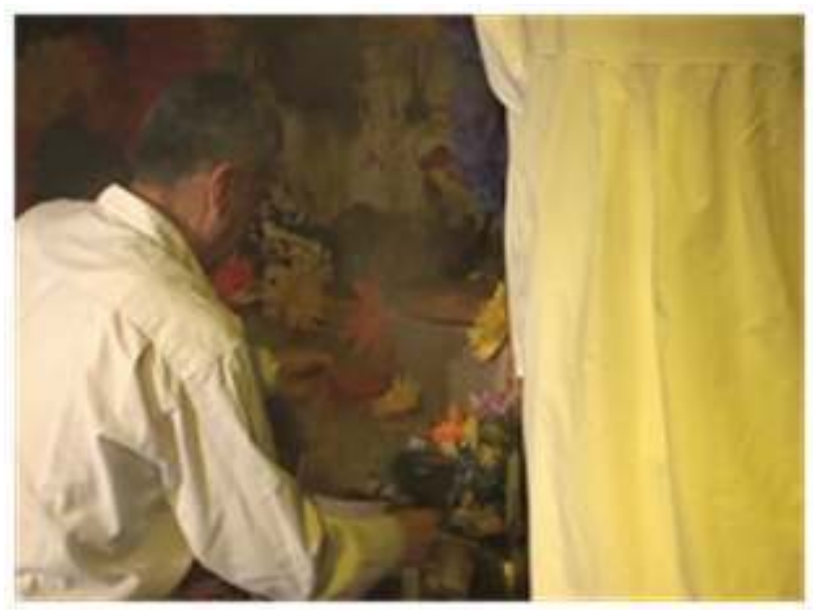

Screenshot: Susanne Schmitt

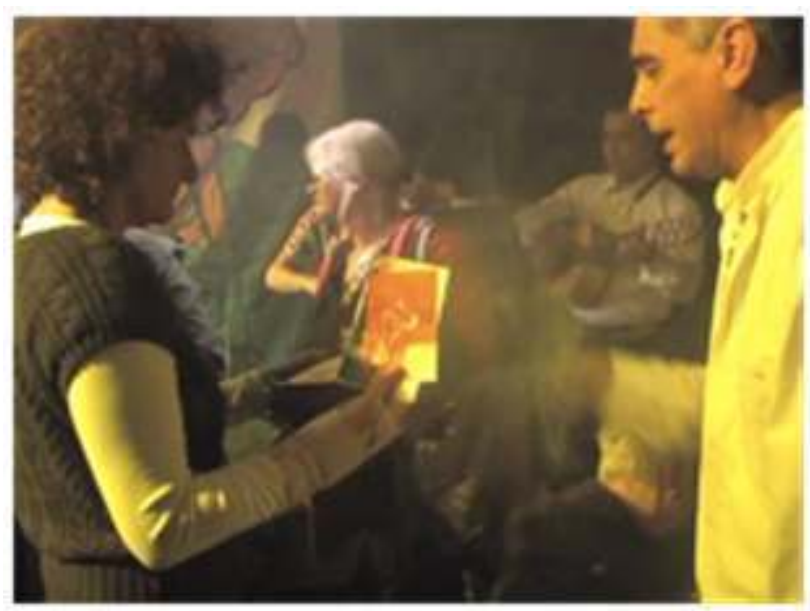


The presents for the ofrenda are being sanctified with copal, producing the typical smell

Screenshot: Susanne Schmitt

Cigarettes and images of lost friends and family members

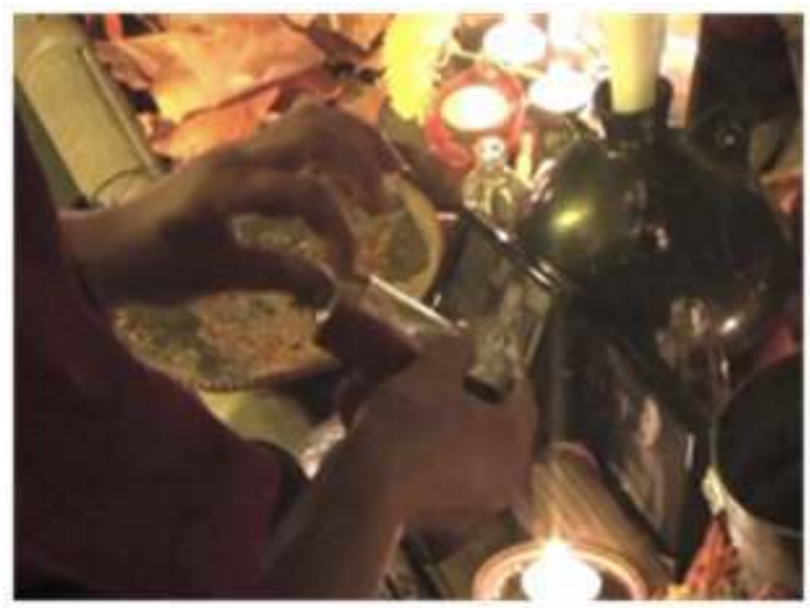

Screenshot: Susanne Schmitt

A side view of the ofrenda during the course of the fiesta

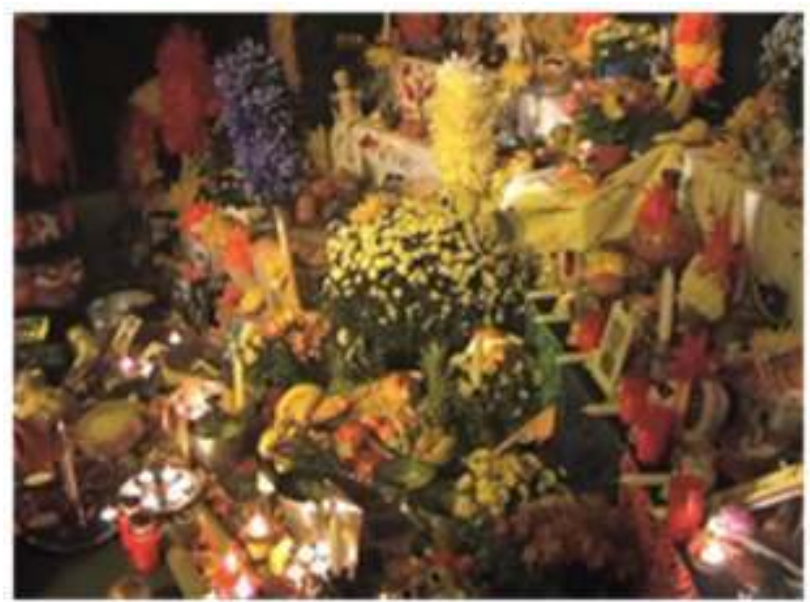

SCREENSHOT: SUSANNE SCHMITT

\section{Holy Mole - Representing the Día de los Muertos as an expression of mimetic visuality}

41 The process of filming the Day of the Dead in Berlin was merely one step within a staggered process of translation that began with a brainstorming on a sunny museum terrace and, moving along different sites and pathways, ended at the museum's cutting room.

42 My position within this process of formation included choosing motifs for the footage and mediating between the cultural brokers involved. Mary Bouquet introduces the term apprenticeship in seeing to describe the work of museum photographers responsible for 
inventory and documentation as an (2001: 187). During the long and dynamic process of exhibition making, images are both the technical basis for palpable decisions and prostheses that make the imaginary and imagined final exhibit a more tangible taskscape for the practitioners involved. While shooting the footage, I followed the curators' and thus developed my own way of seeing as part of my fieldwork project. While shooting the footage, I therefore followed the exhibition team's thoughts and wishes to "show as much food as possible", and to show the "dense atmosphere" of the event. As I have outlined above, this atmosphere was strongly influenced by shifts and passages created through smellscapes and sounds as well as other tools of conscious sensory creation:

"Suspended, temporarily overwhelmed, the self experiences pleasurable disarray, the precondition for returning to itself in a heightened state. In urban first-world cities, where perfumes are most concentrated, I think we have a comparable dynamic, the sublime in miniature and in reverse. You spray on perfume to draw attention to yourself as subject, to mark the distance between yourself and others. In what is known as the scent circle, the space an arm's length around you, perfume marks your subjectivity as potentially sublime in its effect on others."

(Brant 2008: 547.)

So how could this dense atmosphere possibly be conveyed beyond the "visual tyranny of the image" (Taussig 1993: 57)? In her book The Skin of the Film: Intercultural Cinema, Embodiment, and the Senses (2000), Laura Marks convincingly argues that we always perceive of filmic representations multi-sensorially through imagination. She offers a theory of haptic and "embodied visuality" that is based on the mimetic relationship between self and other (2000: 145). According to Marks, images always encompass multisensory qualities and are not exclusively entangled with visual and verbalized expression. Because the images evoke memories and personal experience, they can never just be merely visual but touch upon a plurality of sensoria. Depending on the viewer's positioning, the sensory evocations of the image are ever-changing and bound up so that filmic images can be understood as membranes rather than screens. This positioning of the viewer, however, is also being influenced by the site of the viewing and the specific sensory experiences and politics this site enables.

\section{Sensory politics and mimetic visuality in a process of sensory translation}

44 Sites of cultural representation utilize specific sensory strategies in order to convey meaning, create bodily resonance and attract and cater to specific audiences. While different museums employ the senses in a variety of ways in their exhibition making projects, the representation of todos santos at the Hygiene-Museum was based on the visual - and to a lesser extent audiovisual- display of objects, some of them even models of foodstuffs common to the event. The video footage, which was later turned into a short piece that gathered atmospheric impressions of the event without additional narration, was thought of as conveying the dense social and sensory texture thereof. This visual representation was situated in a context that did not allow for smells or the recreation of an all-encompassing place out of space, a dimension that was highly important to the performance of the event in Berlin. The sensory experience of the museum visitors thus depends on their own ability to imagine, to resonate with the visual display and the audioscape of the media display. The Mexican cultural society specifically advertised the "Day of the Dead" as an event that was aimed "at all senses" including new culinary 
experiences. The ritual performance of calling and inviting the deceased was strongly based on olfactory clues and the heat of the crowd, the candles and the reverberating of the violin music. Since both exhibit-making and ethnographic research and writing are processes of translation, paying attention to the sensory prioritization of sites that enable contact between audiences is a fruitful approach that also helps us better to understand the possibilities and challenges of visual representation in an act of translation.

\section{BIBLIOGRAPHY}

Adapon, Joy (2008): Culinary art and anthropology. Oxford, New York: Berg.

Adorno, Theodor W. (1997): Valery Proust Museum. In: Gesammelte Schriften. Kulturkritik und Gesellschaft I. Frankfurt a. M.: Suhrkamp.

Ames, Michael M. (1992): Cannibal Tours and Glass Boxes: The Anthropology of Museums. Vancouver: Univ. of British Columbia Press.

Bell, Catherine (1997): Ritual. Perspectives and dimensions. New York: Oxford Univ. Press.

Bennett, Tony (2008): Civic Seeing: Museums and the Organization of Vision. In: Macdonald, Sharon (Hg.): A companion to museum studies. Malden, MA: Blackwell, p. 263-281.

Bouquet, Mary (2001): Introduction: Academic Anthropology and the Museum. Back to the Future. In: Bouquet, Mary (ed.): Academic anthropology and the museum. Back to the future. New York: Berghahn Books (New directions in anthropology, 13), p. 1-17.

Brandes, Stanley H. (2006): Skulls to the living, bread to the dead. [the Day of the Dead in Mexico and beyond]. Malden, Mass.: Blackwel

Brant, Clare. "Scenting a Subject: Odour Poetics and the Politics of Space". Ethnos. Journal of Anthropology. 27.4 (2008): 544-5

Carmichael, Elizabeth und Chloe Sayer (2007): Feasting with Dead Souls. In: Korsmeyer, Carolyn (ed.): The taste culture reader. Experiencing food and drink. Oxford: Berg, p. 184-192.

Classen, Constance (2007): Museum Manners: The Sensory Life of the Early Museum. In: Journal of Social History, 40, 4, p. 895-914.

Classen, Constance; Howes, David (2006): The Museum as Sensescape: Western Sensibilities and Indigenuous Artifacts. In: Edwards, Elizabeth; Gosden, Chris; Phillips, Ruth B. (Hg.): Sensible objects. Colonialism, museums and material culture. Engl. ed. Oxford: Berg, p. 199-222.

Clifford, James. Routes: Travel and translation in the late twentieth century. Cambridge, Mass.: Harvard Univ. Press, 1999.

Gell, Alfred (1998): Art and agency. An anthropological theory. Oxford: Clarendon Press. Grasseni, Cristina (2008): Learning to See: World-views, Skilled Visions, Skilled Practice. In: Halstead, Narmala; Hirsch, Eric; Okely, Judith (Hg.): Knowing how to know. Fieldwork and the ethnographic present. New York: Berghahn Books. 
Haley, Shawn D.; Fukuda, Curt (2006): The day of the dead. When two worlds meet in Oaxaca.. New York: Berghahn Books.

Law, Lisa (2006): Home Cooking: Filipino Women and Geographies of the Senses in Hong Kong. In: Howes, David (Hg.): Empire of the Senses: the Sensual Culture Reader. Oxford: Berg, p. 224-243.

Lemke, Harald (2009): Vorwort. Vor der Speise. In: Därmann, Iris (ed.): Die Tischgesellschaft. Philosophische und kulturwissenschaftliche Annäherungen. Bielefeld: transcript-Verlag, p. 7-14.

Losche, Diane (2006): The Fate of the Senses in Ethnographic Modernity: the Margaret Mead Hall of Pacific Peoples at the American Museum of Natural History. In: Edwards, Elizabeth; Gosden, Chris; Phillips, Ruth B. (ed.): Sensible objects. Colonialism, museums and material culture. Engl. ed. Oxford: Berg, p. 223-244.

Marchi, Regina M. (2009): Day of the Dead in the USA. The Migration and Transformation of a Cultural Phenomenon. New York: Rutgers University Press.

Marks, Laura U. (2007): The skin of the film. Intercultural cinema, embodiment, and the senses. [Repr.]. Durham: Duke Univ. Press.

Münster, Daniel (2001): Religionsästhetik und Anthropologie der Sinne. München: Akad. Verlag. Noschka-Roos, Annette; Teichmann, Jürgen (2006): Populäre Wissenschaft in Museen und Science Centers. In: Faulstich, Peter (Hg.): Öffentliche Wissenschaft. Neue Perspektiven der Vermittlung in der wissenschaftlichen Weiterbildung. Bielefeld: transcript-Verlag (Theorie Bilden), p. 87-103. Porteous, John Douglas (1990): Landscapes of the mind. World of sense and metaphor. Toronto: Univ. of Toronto Pr.

Rodaway, Paul (1994): Sensuous geographies. Body, sense and place. London: Routledge.

Schildkrout, Enid (2006): The Beauty of Science and the Truth of Art: Museum Anthropology at the Crossroads. In: Grewe, Cordula (Hg.): Die Schau des Fremden. Ausstellungskonzepte zwischen Kunst, Kommerz und Wissenschaft. Stuttgart: Steiner, p. 119-142.

Schmidt-Welle, Friedhelm (2011): Mexiko als Metapher. Inszenierungen des Fremden in Literatur und Massenmedien. Berlin: Tranvía.

Seremetakis, Constantina Nadia (1996): Intersection: Benjamin, Bloch, Braudel, Beyond. In: Seremetakis, Constantina Nadia (ed.): The senses still. Perception and memory as material culture in modernity. University of Chicago Press ed. Chicago: University of Chicago Press, p. 1922.

Taussig, Michael T. (1993): Mimesis and alterity. A particular history of the senses. New York, NY: Routledge.

Turner, Victor W. (2000): Das Ritual. Struktur und Anti-Struktur. Frankfurt: Campus-Verl.

\section{NOTES}

1. Museums have repeatedly been compared to cemeteries, especially with reference to art museums, maybe most prominently by Theodor Adorno (1997). According to Adorno, the resemblance of "museum" and "mausoleum" is more than a simply phonetic one because both settings function as neutralizers of the living.

2. Among other experiential and interactive features the team and I tested a "smell computer" that had been designed by the university hospital's otolaryngology 
department in cooperation with the museum. It produced a variety of aromatic substances that visitors were then asked to identify on a touchscreen. The computer was later discarded because it appeared to be too strictly modelled after a biomedical testing scenario and did not accentuate the hedonistic dimension of the olfactory in food practices.

3. I refer to a specific use of the term "scape" that has been developed by Douglas Porteous and refined by Paul Rodaway with reference to possible uses in sensory ethnography. It refers to the different sensorial layers of places and the ways in which those are overlapping, experienced and created.

4. Originally in German: "Wir verwandeln den Veranstaltungsort in einen mexikanischen Markt, auf dem leckere, original mexikanische Speisen und Getränke kredenzt werden, als da sind Zuckergebäck und süßes Hefebrot, das zum Totenfest gebacken wird. [...] Das mexikanische Totenfest richtet sich an alle kulturell aufgeschlossenen Menschen, große und kleine, die sich dem Thema Tod auf eine ungewöhnliche Art nähern wollen. In Deutschland setzt sich zunehmend die Erkenntnis durch, dass der Tod nicht verdrängt und tabuisiert werden sollte, dass Abschiednehmen nicht in festgelegten Bahnen verlaufen sollte, sondern dass Tod, Abschied und Trauer zu unserem Leben dazugehören und deshalb ihren Platz brauchen." (http:// www.calaca.de, 20.5.2010).

\section{ABSTRACTS}

Todos santos, or día de los muertos, is one of the most important and globally most visible Mexican festivities celebrating the return of the dead to their families, through the enticement of their favorite foodstuffs. This article looks ethnographically at the re-design of an exhibition on food as part of the re-modeling of the permanent exhibition at the Deutsches Hygiene-Museum in Dresden. This re-design contains an audiovisual representation of todos santos. Based on the author's participation in the process of planning the exhibition with the team of curators in the course of its design and filming todos santos in a Mexican community in Berlin for this museum exhibition, sensory re-and de- contextualization and the question of sensory authorship are discussed.

Todos santos, or día de los muertos est une des fêtes les plus connues et les plus visibles des cérémonies mexicaines qui commémorent le retour des morts auprès de leur famille grâce à la tentation provoquée lors de la préparation de leurs plats préférés. Cet article nous propose une observation ethnographique de la recomposition d'une exposition sur la nourriture au sein de la reconfiguration d'une exposition permanente du Deutsches Hygiene-Museum à Dresde. Cette transformation inclue une représentation audiovisuelle de todos santos. L'article s'appuie et analyse la participation de l'auteure au processus de conceptualisation en lien avec l'équipe des conservateurs dans le déroulement de sa modélisation. L'expérience filmique de todos santos, dans l'exposition, ainsi que les expériences sensorielles décontextualisées ou recontextualisées et la dimension de paternité sensorielle seront au cœur des enjeux et l'analyse du processus engagé.

Todos santos, o día de los muertos, es una de las fiestas mexicanas más importantes y visibles que celebra el retorno de los muertos a sus familias. Para lograr dicho retorno, se seduce a los muertos con sus comidas favoritas. Este artículo propone una mirada etnográfica sobre el 
rediseño de una exposición sobre comida que incluye una representación audiovisual de todos santos y que forma parte de la remodelación de la exposición permanente del Deutsches HygieneMuseum de Dresden. Basado en mi propia participación en el proceso de planificación de la exposición (juntamente con el equipo de comisarios) que incluye el diseño y filmación de todos santos en una comunidad mexicana en Berlín, este artículo aborda la discusión de la recontextualización y la descontextualización sensorial, así como la cuestión de la autoría sensorial.

\section{INDEX}

Mots-clés: todos santos, diá de los muertos, festival, nourriture, exposition, Mexique, paternité, contextualisation sensorielle, paternité sensorielle

Keywords: festivities, food, exhibition, Mexico, authorship, sensory contextualization, sensory authorship

Palabras claves: festividad, comida, exposición, paternidad, contextualización sensorial, paternidad sensorial

\section{AUTHOR}

\section{SUSANNE B. SCHMITT}

Institut für Ethnologie,University of Munich 